\title{
Saxeibacter lacteus gen. nov., sp. nov., an actinobacterium isolated from rock
}

\author{
Soon Dong Lee, Sang Kyu Park, Yoe-Won Yun and Dong Wan Lee \\ Department of Science Education, Cheju National University, Jeju 690-756, Republic of Korea
}

Correspondence

Soon Dong Lee

sdlee@cheju.ac.kr

\begin{abstract}
A Gram-positive, cream-coloured, non-motile, rod-shaped actinomycete, designated DLS-10 ${ }^{\top}$, was isolated from a rock collected on the peak of Darangshi Oreum (a small mountain $300 \mathrm{~m}$ above sea level) in Jeju, Republic of Korea. The temperature and $\mathrm{pH}$ ranges for growth were 4-37 ${ }^{\circ} \mathrm{C}$ and $\mathrm{pH} 5.1-9.1$. The organism grew at $\mathrm{NaCl}$ concentrations up to $3 \%$ and had the following chemotaxonomic characteristics: meso-diaminopimelic acid was the diagnostic diamino acid in the cell-wall peptidoglycan, the polar lipids included diphosphatidylglycerol, phosphatidylmethylethanolamine and two unknown phospholipids, the major menaquinone was MK-8 $\left(\mathrm{H}_{4}\right)$ and the major fatty acids were anteiso- $\mathrm{C}_{15: 0}, \mathrm{C}_{16: 0}$, iso- $\mathrm{C}_{16: 0}$ and anteiso- $\mathrm{C}_{17: 0 \text {. The }}$ DNA G $+C$ content was 74.3 mol\%. Phylogenetic analyses based on 16S rRNA gene sequences revealed that the organism was related to members of the family Nakamurellaceae in the suborder Frankineae. The most closely related described organisms were the type strains of Humicoccus flavidus (97.1\% sequence similarity) and Nakamurella multipartita (95.2\%). On the basis of the morphological, cultural, physiological, chemotaxonomic and phylogenetic evidence presented here, the organism represents a novel genus and species of the family Nakamurellaceae, for which the name Saxeibacter lacteus gen. nov., sp. nov. is proposed. The type strain of Saxeibacter lacteus is DLS $-10^{\top}\left(=\right.$ KCTC $19285^{\top}=$ DSM $\left.19367^{\top}\right)$.
\end{abstract}

The family Microsphaeraceae was originally proposed by Stackebrandt et al. (1997) to encompass the only (and type) genus, Microsphaera (Yoshimi et al., 1996), on the basis of $16 \mathrm{~S}$ rRNA gene sequences. The nomenclature of the family and genus were later changed to Nakamurellaceae and Nakamurella, respectively (Tao et al., 2004). The family Nakamurellaceae belongs phylogenetically to the suborder Frankineae and currently consists of two genera, Nakamurella (Tao et al., 2004) and Humicoccus (Yoon et al., 2007).

Strain DLS $-10^{\mathrm{T}}$ was isolated from a rock sample collected from the peak of Darangshi Oreum (a small mountain $300 \mathrm{~m}$ above sea level) in Jeju, Republic of Korea. Rock samples ( $1 \mathrm{~g}$ ) were ground to powder using a pestle and suspended in $10 \mathrm{ml}$ sterilized, distilled water. Aliquots of serial dilutions of the sample were transferred to starchcasein agar ( $1 \%$ soluble starch, $0.03 \%$ casein, $0.2 \% \mathrm{KNO}_{3}$, $0.2 \% \quad \mathrm{NaCl}, \quad 0.2 \% \mathrm{KH}_{2} \mathrm{PO}_{4}, \quad 0.002 \% \mathrm{CaCO}_{3}, \quad 0.005 \%$ $\mathrm{MgSO}_{4} \cdot 7 \mathrm{H}_{2} \mathrm{O}, \quad 0.001 \% \mathrm{FeSO}_{4} \cdot 7 \mathrm{H}_{2} \mathrm{O}$ and $1.8 \%$ agar; $\mathrm{pH}$ 7.2) and incubated at $30{ }^{\circ} \mathrm{C}$ for 7 days. The isolate

The GenBank/EMBL/DDBJ accession number for the $16 \mathrm{~S}$ rRNA gene sequence of strain DLS-10 ${ }^{\top}$ is AM778124.

A transmission electron micrograph of cells of strain DLS- $10^{\top}$ and details of the cellular fatty acid profiles of strain DLS- $10^{\top}$ and its phylogenetic neighbours are available as supplementary material with the online version of this paper. was maintained as a $20 \%$ glycerol suspension at -20 and $-80{ }^{\circ} \mathrm{C}$. For physiological and chemotaxonomic comparisons, Humicoccus flavidus KCTC $19127^{\mathrm{T}}$ was grown on trypticase soy agar (TSA; Difco) at $30{ }^{\circ} \mathrm{C}$.

Cell morphology and motility were observed by using phase-contrast microscopy. The presence of flagella was checked with a transmission electron microscope (JEM1010; JEOL), using cells negatively stained with $2 \%$ phosphotungstic acid. Colony morphology and pigmentation were observed on a TSA plate incubated for 5 days at $30{ }^{\circ} \mathrm{C}$. Growth was tested at $0,4,10,30,37$ and $42{ }^{\circ} \mathrm{C}$ and at initial pHs in the range 4.1-12.1 (with increments of 1 $\mathrm{pH}$ unit, adjusted using $\mathrm{HCl}$ or $\mathrm{NaOH}$ prior to sterilization). Tolerance of $\mathrm{NaCl}$ was determined on TSA amended with 1-9\% $\mathrm{NaCl}(\mathrm{w} / \mathrm{v})$. The following physiological tests were performed as described previously (Seo \& Lee, 2006): Gram staining, utilization of carbohydrates, oxidase and catalase activities and hydrolysis of aesculin, casein, elastin and starch, hypoxanthine, DL-tyrosine and xanthine. Hydrolysis of chitin and cellulose was checked on TSA supplemented with $0.5 \%(\mathrm{w} / \mathrm{v})$ colloidal chitin and $0.5 \%$ (w/v) CM-cellulose (Sigma), respectively. Anaerobic growth was tested using the GasPak EZ Anaerobe Pouch System (BD) according to the manufacturer's instructions. Acid production from carbohydrates was determined using OF basal medium (Difco) that included each filtersterilized compound at a final concentration of $1 \%$ 
$(\mathrm{w} / \mathrm{v})$. Other physiological and biochemical properties were tested using API 20E and API ZYM strips (bioMérieux) according to the manufacturer's instructions. For these tests, cells were grown on TSA for 3 days at $30{ }^{\circ} \mathrm{C}$ and suspended in a solution of $0.85 \%(\mathrm{w} / \mathrm{v}) \mathrm{NaCl}$. The cells of strain DLS- $10^{\mathrm{T}}$ were Gram-positive, aerobic, catalasepositive, oxidase-negative, non-mycelium-forming, nonmotile, short rods (see Supplementary Fig. S1, available in IJSEM Online). The data on cultural, physiological and biochemical properties are summarized in the species description and Table 1.

DNA isolation and PCR amplification and sequencing of the 16S rRNA gene were performed as described previously (Seo \& Lee, 2006). The CLUSTAL_X program (Thompson et al., 1997) was used for multiple alignment of the sequence determined in this study with the corresponding sequences retrieved from public databases. Phylogenetic analyses were performed using the DNAML, DNAPARS and NEIGHBOR programs contained in the PHYLIP package (Felsenstein, 1993). A phylogenetic tree was constructed using the model of Jukes \& Cantor (1969) and the neighbour-joining method (Saitou \& Nei, 1987). A bootstrap analysis (Felsenstein, 1985) was performed with 1000 replicated datasets.

An almost-complete 16S rRNA gene sequence (1399 nt) of strain DLS- $10^{\mathrm{T}}$ was compared with those of representatives of the suborder Frankineae and related taxa. The results of phylogenetic analyses based on 16S rRNA gene sequences showed that the organism formed a consistent clade with members of the family Nakamurellaceae (Fig. 1), with high bootstrap support $(100 \%)$. The most closely related described neighbours were H. flavidus DS- $52^{\mathrm{T}}(97.1 \% 16 \mathrm{~S}$ rRNA gene sequence identity) and Nakamurella multipartita JCM $9543^{\mathrm{T}}(95.2 \%)$. Strain DLS- $10^{\mathrm{T}}$ shared a $16 \mathrm{~S}$ rRNA gene sequence similarity of $99.1 \%$ with respect to an undescribed strain, Actinomycetales bacterium Gsoil 972.

Cell biomass of strain DLS- $10^{\mathrm{T}}$ and H. flavidus KCTC $19127^{\mathrm{T}}$ for chemotaxonomic analyses was obtained from cultures grown in trypticase soy broth (Difco) at $30{ }^{\circ} \mathrm{C}$. Analysis of the cell-wall peptidoglycan (Staneck \& Roberts,

Table 1. Differential characteristics between strain DLS $-10^{\top}$ and related taxa of the family Nakamurellaceae

Data for H. flavidus KCTC $19127^{\mathrm{T}}$ were taken from Yoon et al. (2007) and this study, and data for N. multipartita JCM $9543^{\mathrm{T}}$ were taken from Yoshimi et al. (1996) and Yoon et al. (2007). All showed growth at $10-32{ }^{\circ} \mathrm{C}, \mathrm{pH} 5.1-8.1$ and in the presence of up to $3 \%$ (w/v) NaCl. All were positive for the Gram stain, catalase activity, hydrolysis of aesculin and utilization of D-galactose and glycerol. All were negative for motility, oxidase activity, hydrolysis of DL-tyrosine and xanthine, anaerobic growth and utilization of acetate. +, Positive; -, negative; w, weak; ND, not described.

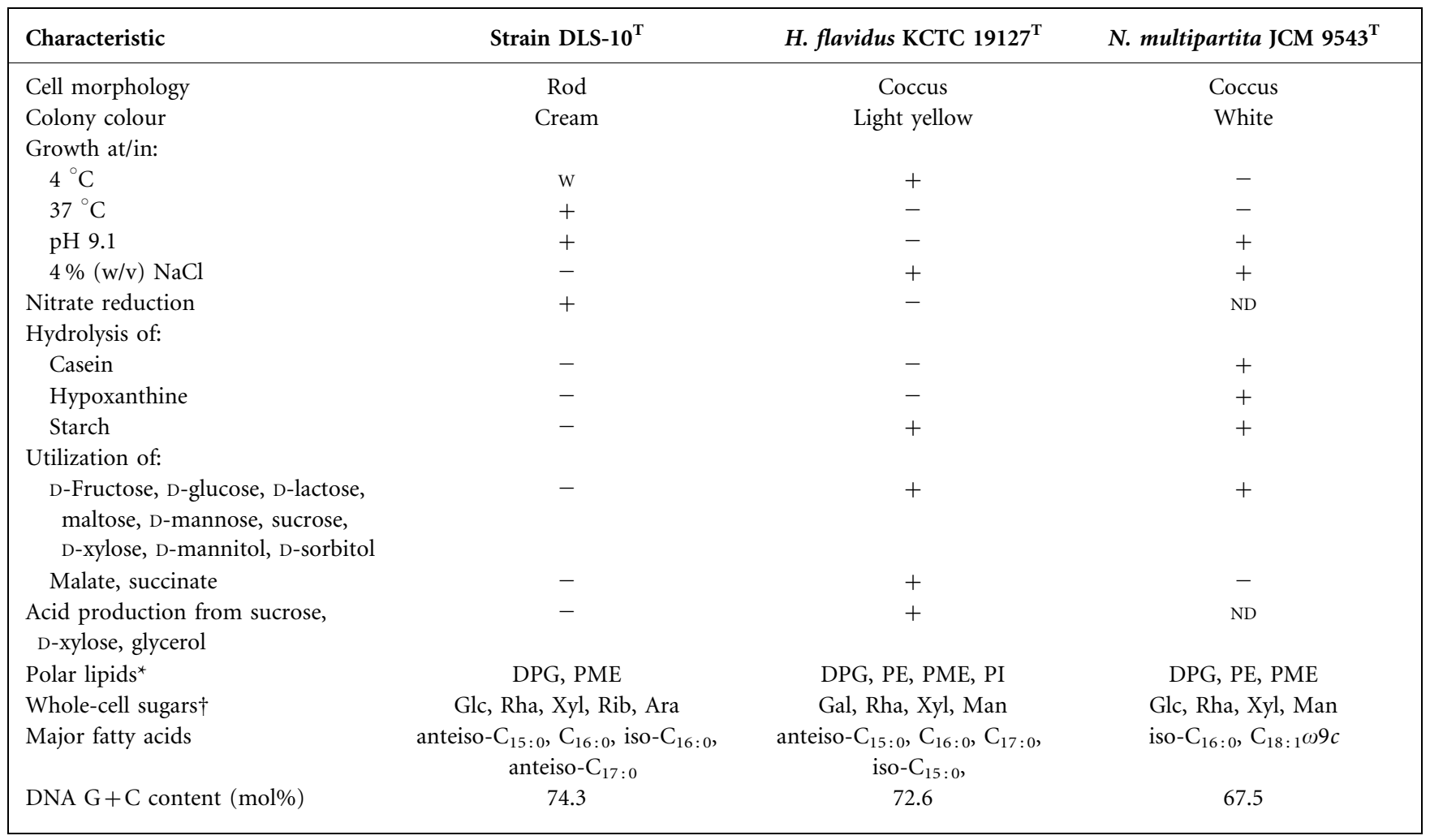

${ }^{\star}$ DPG, Diphosphatidylglycerol; PE, phosphatidylethanolamine; PI, phosphatidylinositol; PME, phosphatidylmethylethanolamine. $\dagger$ Ara, Arabinose; Gal, galactose, Glc, glucose; Man, mannose; Rha, rhamnose; Rib, ribose; Xyl, xylose. Sugars are listed in decreasing order of abundance. 


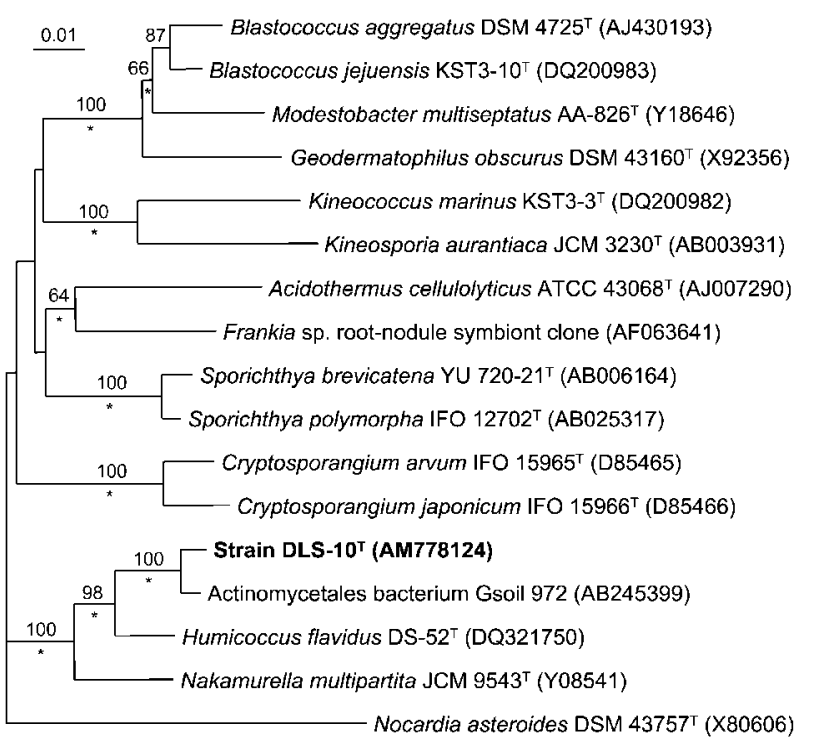

Fig. 1. Neighbour-joining phylogenetic tree, based on $16 \mathrm{~S}$ rRNA gene sequences, showing the phylogenetic position of strain DLS$10^{\top}$ within the radiation of the family Nakamurellaceae and related taxa. Asterisks indicate branches that were also supported by both the maximum-likelihood (Felsenstein, 1981) and maximum-parsimony (Fitch, 1971) methods. Bootstrap analysis was based on a neighbour-joining analysis of 1000 resampled datasets (values above $50 \%$ are shown at nodes). Bar, 0.01 substitutions per nucleotide position.

1974) of strain DLS- $10^{\mathrm{T}}$ showed that it contained mesodiaminopimelic acid as the diagnostic diamino acid. The whole-cell sugars of the isolate were glucose, rhamnose, xylose, ribose and arabinose (in decreasing order of abundance), as analysed by gas chromatography (Saddler et al., 1991). The menaquinone profile of strain DLS $-10^{\mathrm{T}}$, as determined using HPLC (Kroppenstedt, 1985), contained MK-8 $\left(\mathrm{H}_{4}\right), \mathrm{MK}-9\left(\mathrm{H}_{0}\right), \mathrm{MK}-7\left(\mathrm{H}_{0}\right)$ and $\mathrm{MK}-8\left(\mathrm{H}_{2}\right)$ (peak ratio, 66:12:12:10). It was reported by Yoon et al. (2007) that the predominant menaquinones in $H$. flavidus KCTC $19127^{\mathrm{T}}$ are MK-8 $\left(\mathrm{H}_{4}\right)$ and MK-9 $\left(\mathrm{H}_{4}\right)$, but the latter was not detected in our study. Analysis of the polar lipids by TLC (Minnikin et al., 1977) revealed that diphosphatidylglycerol, phosphatidylmethylethanolamine and two unknown phospholipids were present in extracts of the isolate, but phosphatidylethanolamine, phosphatidylcholine and phosphatidylinositol were not present. In contrast, $H$. flavidus KCTC $19127^{\mathrm{T}}$ was shown to contain a considerable amount of phosphatidylinositol in addition to the polar lipids reported previously (Yoon et al., 2007). The $\mathrm{G}+\mathrm{C}$ content of the DNA was determined by HPLC as described by Mesbah et al. (1989): the value for strain DLS$10^{\mathrm{T}}$ was $74.3 \mathrm{~mol} \%$.

The cellular fatty acid compositions of strain DLS- $10^{\mathrm{T}}$ and H. flavidus KCTC $19127^{\mathrm{T}}$ were determined using the Sherlock Microbial Identification System (version 6.0; MIDI) according to the manufacturer's instructions, using cells grown on TSA at $30{ }^{\circ} \mathrm{C}$ for 5 days. The predominant fatty acids of the isolate were anteiso- $\mathrm{C}_{15: 0}(25.8 \%), \mathrm{C}_{16: 0}$ $(19.6 \%)$, iso- $\mathrm{C}_{16: 0}(15.7 \%)$ and anteiso- $\mathrm{C}_{17: 0}(15.0 \%)$, while those of $\mathrm{H}$. flavidus KCTC $19127^{\mathrm{T}}$ were anteiso- $\mathrm{C}_{15: 0}$ $(27.7 \%), \mathrm{C}_{16: 0}(13.7 \%), \mathrm{C}_{17: 0}(13.0 \%)$ and iso- $\mathrm{C}_{15: 0}$ $(10.7 \%)$. Strain DLS-10 ${ }^{\mathrm{T}}$ differed significantly from $H$. flavidus KCTC $19127^{\mathrm{T}}$ in the relative amounts of $\mathrm{C}_{17: 0}$, iso$\mathrm{C}_{16: 0}$, iso- $\mathrm{C}_{15: 0}$ and anteiso- $\mathrm{C}_{17: 0}$ and with respect to the absence/presence of $\mathrm{C}_{17: 1} \omega 6 c$ and anteiso- $\mathrm{C}_{15: 0} 2-\mathrm{OH}$ (see the cellular fatty acid profiles in Supplementary Table S1). N. multipartita DSM $44233^{\mathrm{T}}$ is clearly distinguishable from strain DLS- $10^{\mathrm{T}}$ in that the predominant fatty acids in the former are iso- $C_{16: 0}$ and $C_{18: 1} \omega 9 c$ (Yoon et al., 2007).

In addition to the major differences in the fatty acid profile, strain DLS $-10^{\mathrm{T}}$ can be readily differentiated from $H$. flavidus and N. multipartita on the basis of cell morphology and colony pigmentation. Cells of the isolate are short rods and produce cream-coloured colonies, whereas the type strains of $H$. flavidus and N. multipartita are coccoid in shape and produce light yellow- or white-coloured colonies. Strain DLS-10 ${ }^{\mathrm{T}}$ also differs from the type strains of $H$. flavidus and $N$. multipartita in that it lacks phosphatidylethanolamine and phosphatidylinositol in the polar lipid profile. Other differential characteristics for strain DLS- $10^{\mathrm{T}}$ and the type strains of $H$. flavidus and N. multipartita are summarized in Table 1.

On the basis of morphological, cultural, physiological and chemotaxonomic data, as well as phylogenetic distinctness, strain DLS- $10^{\mathrm{T}}$ represents a novel genus and species of the family Nakamurellaceae, for which the name Saxeibacter lacteus gen. nov., sp. nov. is proposed.

\section{Description of Saxeibacter gen. nov.}

Saxeibacter (Sa.xe.i.bac'ter. L. adj. saxeus of rock; N.L. masc. n. bacter a rod; N.L. masc. n. Saxeibacter a rod isolated from rock).

Cells are aerobic, Gram-positive, oxidase-negative, catalase-positive, non-mycelium-forming, non-motile, short rods $(0.4-0.7 \times 0.9-1.0 \mu \mathrm{m})$. The isomer of diamino acid in the cell-wall peptidoglycan is meso-diaminopimelic acid. The whole-cell sugars are glucose, rhamnose, xylose, ribose and arabinose. The major menaquinone is $\mathrm{MK}-8\left(\mathrm{H}_{4}\right)$. The polar lipids include diphosphatidylglycerol, phosphatidylmethylethanolamine and two unknown phospholipids. The predominant fatty acids are anteiso- $\mathrm{C}_{15: 0}, \mathrm{C}_{16: 0}$, iso- $\mathrm{C}_{16: 0}$ and anteiso- $\mathrm{C}_{17: 0}$. The DNA $\mathrm{G}+\mathrm{C}$ content of the type strain of the type species is $74.3 \mathrm{~mol} \%$. On the basis of $16 \mathrm{~S}$ rRNA gene sequence studies, the genus belongs to the family Nakamurellaceae in the suborder Frankineae. The type species for the genus is Saxeibacter lacteus.

\section{Description of Saxeibacter lacteus sp. nov.}

Saxeibacter lacteus (lac.te' us. L. masc. adj. lacteus milkcoloured, milky). 
Colonies are cream-coloured, circular, smooth and convex, reaching $0.5-1.0 \mathrm{~mm}$ in diameter. The morphological and chemotaxonomic characteristics are the same as those given in the genus description. The temperature and $\mathrm{pH}$ ranges for growth are $4-37^{\circ} \mathrm{C}$ and $\mathrm{pH}$ 5.1-9.1. No growth occurs at 0 or $42{ }^{\circ} \mathrm{C}$, at $\mathrm{pH} 4.1$ or above $\mathrm{pH} 10.1$. Grows at $\mathrm{NaCl}$ concentrations up to $3 \%$; does not grow in the presence of $4 \% \mathrm{NaCl}$. Positive for hydrolysis of DNA; negative for hydrolysis of chitin, CM-cellulose and elastin. Nitrate is reduced to nitrite. The following tests in the API $20 \mathrm{E}$ system are negative: $\mathrm{H}_{2} \mathrm{~S}$ production, utilization of citrate, indole production and Voges-Proskauer reaction, arginine dihydrolase, lysine decarboxylase, ornithine decarboxylase, urease, tryptophan deaminase and gelatinase. In the API ZYM system, tests for leucine arylamidase, valine arylamidase, $\beta$-galactosidase, $\alpha$-glucosidase, $N$ acetyl- $\beta$-glucosaminidase and $\alpha$-mannosidase are positive. Weakly positive for esterase lipase (C8) and acid phosphatase. Negative for alkaline phosphatase, esterase (C4), lipase (C14), cystine arylamidase, trypsin, $\alpha$-chymotrypsin, naphthol-AS-BI-phosphohydrolase, $\alpha$-galactosidase, $\beta$-glucuronidase, $\beta$-glucosidase and $\alpha$-fucosidase. L-Arabinose, myo-inositol and methyl $\alpha$-D-mannoside are utilized as sole carbon and energy sources, but benzoate, cellobiose, citrate, dextran, D-dulcitol, meso-erythritol, formate, methyl $\alpha$-D-glucoside, inulin, melezitose, raffinose, Lrhamnose, salicin, L-sorbose, DL-tartrate, trehalose and Dxylitol are not used. Acid is produced from D-galactose. Other physiological properties are given in Table 1. The predominant fatty acids are anteiso- $\mathrm{C}_{15: 0}(25.8 \%), \mathrm{C}_{16: 0}$ $(19.6 \%)$, iso- $\mathrm{C}_{16: 0}(15.7 \%)$ and anteiso- $\mathrm{C}_{17: 0}(15.0 \%)$. The DNA G $+\mathrm{C}$ content is $74.3 \mathrm{~mol} \%$.

The type strain, DLS $-10^{\mathrm{T}} \quad\left(=\right.$ KCTC $19285^{\mathrm{T}}=\mathrm{DSM}$ $19367^{\mathrm{T}}$ ), was isolated from a rock sample collected from the peak of Darangshi Oreum (a small mountain, $300 \mathrm{~m}$ above sea level) in Jeju, Republic of Korea.

\section{Acknowledgements}

This work was supported by the 21C Frontier Microbial Genomics and Application Center Program, Ministry of Science and Technology, Republic of Korea, and by a research grant (in 2007) from the Cheju National University. The authors are grateful to Dr Jung-Sook Lee (Korean Collection for Type Cultures) for providing the type strain of $H$. flavidus, and to Dr Ruediger Pukall for kind discussions concerning the genus description.

\section{References}

Felsenstein, J. (1981). Evolutionary trees from DNA sequences: a maximum likelihood approach. J Mol Evol 17, 368-376.
Felsenstein, J. (1985). Confidence limits on phylogenies: an approach using the bootstrap. Evolution 39, 783-791.

Felsenstein, J. (1993). PHYLIP (phylogeny inference package), version 3.5c. Department of Genome Sciences, University of Washington, Seattle, USA.

Fitch, W. M. (1971). Toward defining the course of evolution: minimum change for a specific tree topology. Syst Zool 20, 406-416.

Jukes, T. H. \& Cantor, C. R. (1969). Evolution of protein molecules. In Mammalian Protein Metabolism, vol. 3, pp. 21-132. Edited by H. N. Munro. New York: Academic Press.

Kroppenstedt, R. M. (1985). Fatty acid and menaquinone analysis of actinomycetes and related organisms. In Chemical Methods in Bacterial Systematics, pp. 173-199. Edited by M. Goodfellow \& D. E. Minnikin. London: Academic Press.

Mesbah, M., Premachandran, U. \& Whitman, W. B. (1989). Precise measurement of the $\mathrm{G}+\mathrm{C}$ content of deoxyribonucleic acid by high-performance liquid chromatography. Int J Syst Bacteriol 39, 159-167.

Minnikin, D. E., Alshamaony, L. \& Goodfellow, M. (1977). Differentiation of Mycobacterium, Nocardia, and related taxa by thin layer chromatographic analysis of whole-cell methanolysates. J Gen Microbiol 88, 200-204.

Saddler, G. S., Tavecchia, P., Lociuro, S., Zanol, M., Colombo, L. \& Selva, E. (1991). Analysis of madurose and other actinomycete whole cell sugars by gas chromatography. J Microbiol Methods 14, 185-191.

Saitou, N. \& Nei, M. (1987). The neighbor-joining method: a new method for reconstructing phylogenetic trees. Mol Biol Evol 4, 406-425.

Seo, J. P. \& Lee, S. D. (2006). Nocardia harenae sp. nov., an actinomycete isolated from beach sand. Int J Syst Evol Microbiol 56, 2203-2207.

Stackebrandt, E., Rainey, F. A. \& Ward-Rainey, N. L. (1997). Proposal for a new hierarchic classification system, Actinobacteria classis nov. Int J Syst Bacteriol 47, 479-491.

Staneck, J. L. \& Roberts, G. D. (1974). Simplified approach to identification of aerobic actinomycetes by thin-layer chromatography. Appl Microbiol 28, 226-231.

Tao, T.-S., Yue, Y.-Y., Chen, W.-X. \& Chen, W.-F. (2004). Proposal of Nakamurella gen. nov. as a substitute for the bacterial genus Microsphaera Yoshimi et al. 1996 and Nakamurellaceae fam. nov. as a substitute for the illegitimate bacterial family Microsphaeraceae Rainey et al. 1997. Int J Syst Evol Microbiol 54, 999-1000.

Thompson, J. D., Gibson, T. J., Plewniak, F., Jeanmougin, F. \& Higgins, D. G. (1997). The CLUSTAL_X windows interface: flexible strategies for multiple sequence alignment aided by quality analysis tools. Nucleic Acids Res 25, 4876-4882.

Yoon, J.-H., Kang, S.-J., Jung, S.-Y. \& Oh, T.-K. (2007). Humicoccus flavidus gen. nov., sp. nov., isolated from soil. Int J Syst Evol Microbiol 57, 56-59.

Yoshimi, Y., Hiraishi, A. \& Nakamura, K. (1996). Isolation and characterization of Microsphaera multipartita gen. nov., sp. nov., a polysaccharide-accumulating Gram-positive bacterium from activated sludge. Int J Syst Bacteriol 46, 519-525. 